\title{
Analysis of high earth-rock cofferdam stability on thick silt ground
}

\author{
F. YAN, R.J. WANG, X.X.HE \& Y.ZHAO \\ Xi'an University of Technology, Xi'an, Shaanxi, China
}

\begin{abstract}
KEYWORD: Thick silt foundation; High earth-rock cofferdam; Slope stability; Treatment measure ABSTRACT: This article researches the measures of thick silt foundation reinforcement and slope stability through the anti-sliding stability analysis. It can be concluded that the reinforcement effects of vibro-replacement stone column is remarkable on thick silt foundation based on reasonable pile spacing and pile diameter, and that it is advantageous for the cofferdam and its downstream foundation pit slope stability to slowing its corresponding slopes and increase heavy pressure. Lastly, taking comprehensive treatment measure is an effective way to solve the slope stability problem of high earth-rock cofferdam and its downstream ground pit slope on thick silt foundation.
\end{abstract}

\section{INTRODUCTION}

Since thick silt foundation wide distribution and shear strength small, it is difficult to satisfy the requirements of stability against sliding of high earth-rock cofferdam and its downstream foundation pit slope building on thick silt foundation. Under the premise of technology feasibly and economic reasonably, foundation reinforcement and slope (including cofferdam and downstream foundation pit slope, similarly hereinafter) stability treatment measures taken to make the cofferdam and its downstream foundation pit slope satisfy the requirements of stability against sliding, which is still key technical problems that water conservancy construction needs further study and solve.

This article bases on a proposed engineering example that is a high earth-rock cofferdam of one large hydropower station, through the contrastive analysis of variety of foundation reinforcement and slope stabilization measures to research the optimum treatment measure that can ensure cofferdam and its downstream foundation pit slope stability against sliding on thick silt foundation.

\section{PROJECT OVERVIEW}

The cofferdam maximum height is about $60.3 \mathrm{~m}$ of the large proposed hydropower station, and its sectional view is shown in Figure 1. The upper cofferdam body uses composite geomembrane sloping wall as seepage control, and lower cofferdam body and foundation use plastic concrete similarly. The vast majority of cofferdam filling materials are decorated with structures excavated materials that mechanical parameters are lower.

The upper lateral earth-rock cofferdam both sides bedrock exposes and the lithology is green clay hornblende schist. The drilling results reveal that the maximum covering layers thickness is about $65 \mathrm{~m}$, and maximum depth of foundation excavation is $70 \mathrm{~m}$ approximately. According to material composition, covering layers can be divided into four layers and I no. lens. From top to bottom in turn as follows: (5) $\mathrm{Q}^{\mathrm{al}-5}$ layer, river alluvial sand pebble bed with small boulders, thickness (location in cofferdam axis, similarly hereinafter) is $4.06 \mathrm{~m}$; (3) $\mathrm{Q}^{\mathrm{al}-3}$ layer, containing muddy powder sand and clay sand, thickness is $14.96 \mathrm{~m}$; (2) $\mathrm{Q}^{\mathrm{al}-2}$ layer, give priority to with sandy and low liquid limit clay, thickness is $31.92 \mathrm{~m}$; (1) $\mathrm{Q}^{\mathrm{al}-1}$ layer, include pebble, stone and sand, thickness is $14.19 \mathrm{~m}$; missing the layer of (4).The (3) 、(2) covering layers belong to silt foundation that total thickness is $46.88 \mathrm{~m}$, and their internal friction angle between 16 18.5 ${ }^{\circ}$ and shear strength index small, which is disadvantageous to maintain the slope stability. 


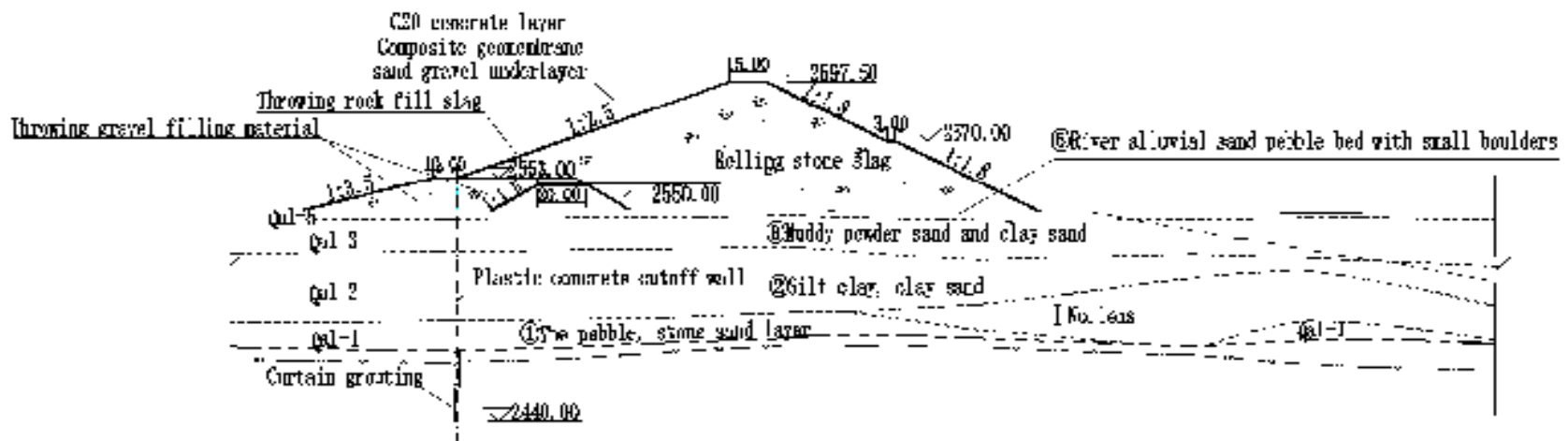

Figure 1. Sectional view of high earth-rock cofferdam.

\section{ANALYSIS ON THE MECHANICS MECHANISM AND EFFECTS OF VIBRO- REPLACEMENT STONE COLUMN APPLIED ON THICK SILT FOUNDATION REINFORCEMENT}

\section{Common measures on thick silt foundation reinforcement}

The measures of thick silt foundation reinforcement are too many, for example excavation backfill, dynamic compaction, high pressure jet grouting and vibro-replacement stone column and many more (Guo \& Wang 2008, Fu 2010). The disadvantages of excavation are large engineering quantity and long construction period. There are certain requirements to foundation soil of dynamic compaction (Zheng \& Lu 2000). And it is not easy to control the project quantity for using high pressure jet grouting. The vibro-replacement stone column not only has significant effect, but construction period is shorter. And some scholars have considered that reinforcement effects of sandy soil and powder soil are most obvious replaced with it (Li 2008, Wang \& Zhang 2004). According to comparison of reinforcement measures, this article considers using vibro-replacement stone column on the thick silt foundation reinforcement.

The mechanics mechanism of vibro-replacement stone column

The technology vibro-replacement stone column utilizes the horizontal vibration form holes under the effects of high pressure water, and then filled with gravel, which replaces silt soil to form high strength piles to improve bearing capacity and shear strength, and to reduce settlement. As can be seen, vibro-replacement stone column play a main role on replacement of thick silt soil foundation (Zhang \& Cao 2007). Meanwhile, the silt foundation has lower permeability so that water in the soil is not easy to drain away under vibrating force, while the rubble piles are good drainage channels and play a role as drainage of sand wells, which can short the horizontal permeability pathways of pore water and accelerate the drainage and consolidation of silt soil.

The reinforcement effects of vibro-replacement stone column

Some scholars (Li 2013,Yu \& Zhang 2007) have studied the influence of different pile spacing on composite foundation, and has considered the shear strength, bearing capacity and penetration number of soil between piles increasing with the pile spacing reducing in other factors being equal.

Lan,B. (Lan 2005) has studied the influence of different pile diameters on settlement, and has considered that the settlement increasing with the pile diameters increased. The reasonable explanation is that large diameters disturbs soil between piles greatly and changes the structure of soft soil, which can result in decreasing of undrained shear strength.

Therefore, the reasonable pile spacing and pile diameter are key factors of vibro-replacement stone column. This article considers using $1.5 \mathrm{~m}$ pile spacing and $1.0 \mathrm{~m}$ pile diameter to carry out the thick silt foundation reinforcement. After processed, composite foundation parameters of (3)

(2) covering layers are shown in Table 1 . As can be seen, the internal friction angle increases from $16 \sim 18.5^{\circ}$ to $24.5 \sim 26^{\circ}$, so the vibro-replacement stone column can effectively improve the shear strength of thick silt foundation. 
Table 1. (3)、 (2)covering layers parameters after reinforcement of vibro-replacement stone column.

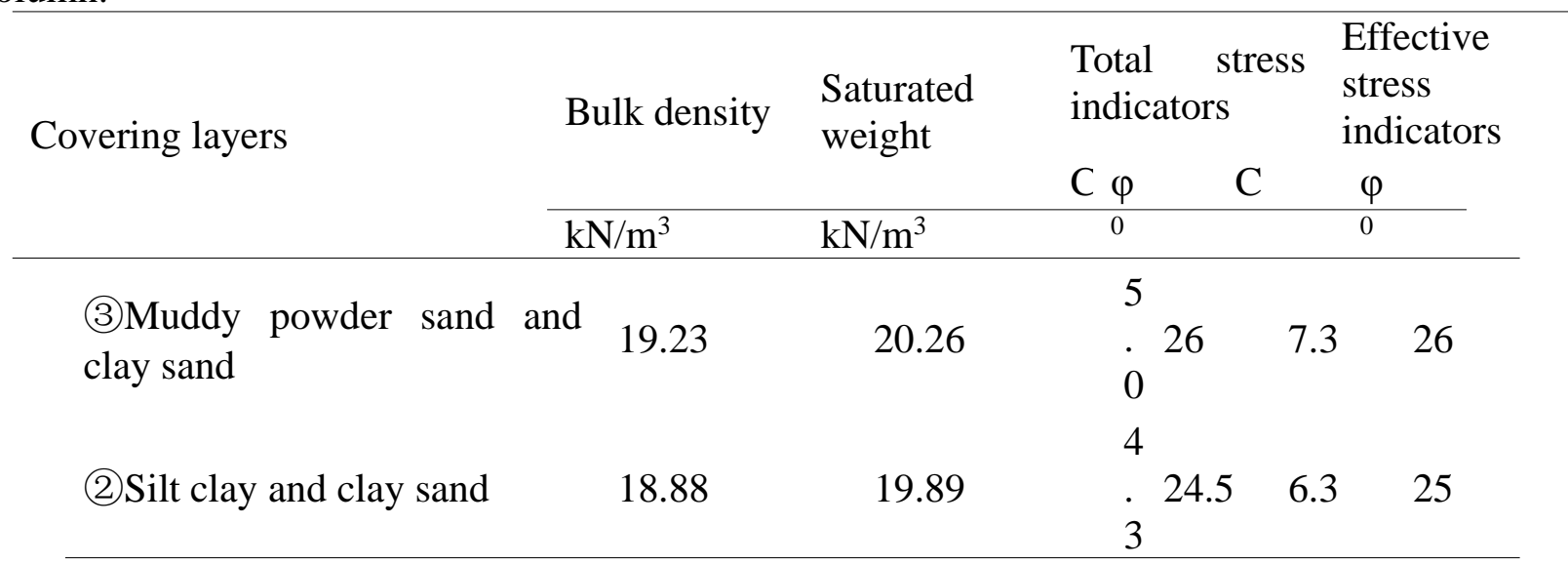

\section{ANALYSIS OF MEASURES TO INCREASE COFFERDAM SLOPE STABILITY}

There are measures of slowing cofferdam slope and foundation pit slope ratio, adding the heave pressure and soon on to increase slope stability. Based on geostudio software, this article analyzes the measures to increase slope stability of high earth-rock cofferdam under various operating conditions comparatively. The analysis of stability uses the Mohr-Coulomb yield criterion. According to 《Design specification for rolled earth-rock fill dam》 (DL/T 5395-2007), the slope stability adopts effective stress indicators and total stress indicators to calculate and uses the minimum results of two indicators as final results during the construction period; identically stable seepage and excavation period uses the effective stress indicators. To control stability calculation results by Morgenstern-Price indicator, Bishop indicator as reference. The computing section is shown in Figure 1, the calculation conditions are shown in Table 2, and the parameters in Table 3.

Figure 2 is a curve between stability safety factors of cofferdam downstream slope and its different ratios. As can be seen, slope stability safety factors increase with its ratio increasing.

Table 2. The calculated conditions of high earth-rock cofferdam stability.

\begin{tabular}{|c|c|c|c|c|c|}
\hline & \multirow{3}{*}{ conditions } & \multirow[b]{2}{*}{ filling height } & \multirow{3}{*}{$\begin{array}{l}\text { Excavation } \\
\text { situation }\end{array}$} & \multicolumn{2}{|l|}{ water level } \\
\hline & & & & upstream & downstream \\
\hline & & $\mathrm{m}$ & & $\mathrm{m}$ & $\mathrm{m}$ \\
\hline $\begin{array}{l}\text { construction } \\
\text { period }\end{array}$ & S-1 & 2553.0 & - & 2550.61 & 2538.00 \\
\hline \multirow{2}{*}{$\begin{array}{l}\text { Stable seepage } \\
\text { period }\end{array}$} & S-2 & 2597.5 & - & 2550.61 & 2538.00 \\
\hline & $\mathrm{S}-3$ & 2597.5 & - & 2595.05 & 2538.00 \\
\hline \multirow{5}{*}{$\begin{array}{l}\text { Excavation } \\
\text { period }\end{array}$} & $\mathrm{K}-1$ & 2597.5 & (5) & 2595.05 & $\begin{array}{l}\text { Foundation } \\
\text { pit bottom }\end{array}$ \\
\hline & $\mathrm{K}-2$ & 2597.5 & (5)(3) & 2595.05 & $\begin{array}{l}\text { Foundation } \\
\text { pit bottom }\end{array}$ \\
\hline & $\mathrm{K}-3$ & 2597.5 & (5)(3)(2) & 2595.05 & $\begin{array}{l}\text { Foundation } \\
\text { pit bottom }\end{array}$ \\
\hline & $\mathrm{K}-4$ & 2597.5 & (5)(3)(2)(1) & 2595.05 & $\begin{array}{l}\text { Foundation } \\
\text { pit bottom }\end{array}$ \\
\hline & $\mathrm{K}-5$ & 2597.5 & (5)(3)(2)(1) & 2550.61 & $\begin{array}{l}\text { Foundation } \\
\text { pit bottom }\end{array}$ \\
\hline
\end{tabular}


Table 3. The stability calculation parameters table of earth-rock cofferdam and covering soil.

\begin{tabular}{|c|c|c|c|c|c|c|}
\hline & \multirow{3}{*}{$\begin{array}{l}\text { Bulk density } \\
\mathrm{kN} / \mathrm{m}^{3}\end{array}$} & \multirow{2}{*}{ Saturated unit weight } & \multicolumn{3}{|c|}{ Total stress indicators } & \multirow{2}{*}{$\begin{array}{l}\text { Effective } \\
\text { stress } \\
\text { indicators }\end{array}$} \\
\hline & & & \multicolumn{3}{|l|}{$\mathrm{C} \varphi$} & \\
\hline & & $\mathrm{kN} / \mathrm{m}^{3}$ & 0 & & & \\
\hline Rolling stone slag & 22.4 & & 038 & & & \\
\hline $\begin{array}{l}\text { Throwing gravel } \\
\text { filling } \\
\text { material(water) }\end{array}$ & 17.9 & & 025 & & & \\
\hline $\begin{array}{l}\text { Throwing gravel } \\
\text { filling } \\
\text { materia(underwater) }\end{array}$ & & 18.4 & 023 & & & \\
\hline $\begin{array}{l}\text { Throwing rock fill } \\
\text { slag(water) }\end{array}$ & 21.5 & & 032 & & & \\
\hline $\begin{array}{l}\text { Throwing rock fill } \\
\text { slag(underwater) }\end{array}$ & & 22.0 & 030 & & & \\
\hline Ino. lens & 20 & 20.5 & 028 & & & \\
\hline $\begin{array}{l}\text { (5) River alluvial sand } \\
\text { pebble bedCliping a } \\
\text { small boulders }\end{array}$ & 20.63 & 21 & 029 & & & \\
\hline $\begin{array}{l}\text { (3)Muddy powder } \\
\text { sand and clay sand }\end{array}$ & 17.45 & 18.5 & 15 & 13 & 22 & 18.5 \\
\hline (2) Silt clay, clay sand & 16.73 & 17.75 & 13 & 10 & 19 & 16 \\
\hline $\begin{array}{l}\text { (1) The pebble, stone } \\
\text { sand layer }\end{array}$ & 20.38 & 20.75 & 0 & 30 & 0 & 31 \\
\hline
\end{tabular}

Add heavy pressure in the same high of plastic concrete cutoff wall construction platform (elevation of $2553 \mathrm{~m}$ ). The effects of different heavy pressure lengths on stability safety factors of each condition cofferdam downstream slope before excavation as shown in Figure 3.As can be seen, stability safety factors of cofferdam downstream slope increases with heavy pressure length increased, but S-1 condition's almost unchanged with heavy pressure length changing. The rational reason is that the height and slope ratio of S-1 condition are consistent with heavy pressure, thus increasing the heavy pressure length equivalent to increase the width of cofferdam section, which does not have an effect on stability augmentation. Based on the principle that can satisfy the stability safety factor requirements of each condition downstream slope before excavation, it can be determined the heavy pressure length should be at least $60 \mathrm{~m}$. The effects of different heavy pressure lengths on stability safety factors of each excavation condition based on previous results are shown in Figure 4.It can be seen that it is more significant for stability safety factors on little depth excavation conditions to increase heavy pressure length, but the opposite is not particularly obvious.

Figure 5 is the curve of foundation pit slope stability safety factors and different foundation pit slope ratios. As can be seen, stability safety factors increase with foundation pit slope ratios increasing, and stability safety factor of $\mathrm{K}-2$ condition is minimum values. It also means that excavating to (3) cover layer is the most unfavorable situation. So it can be carried out the measures that firm partial of (3) cover layer on the basis of slowing down appropriately foundation pit slope ratio.

Through the study measures augmentating slope stability, it's easy to see that the measures of slowing cofferdam slope and foundation pit slope ratio, increasing heavy pressure can effectively increase the safety factors of slope stability. But slowing cofferdam and its foundation pit slope ratios will make the cofferdam and the excavation sections increased, furthermore the heavy pressure is simple and more economic, so it is proposed to select preferentially the heave pressure to satisfy the requirements of slope stability. 


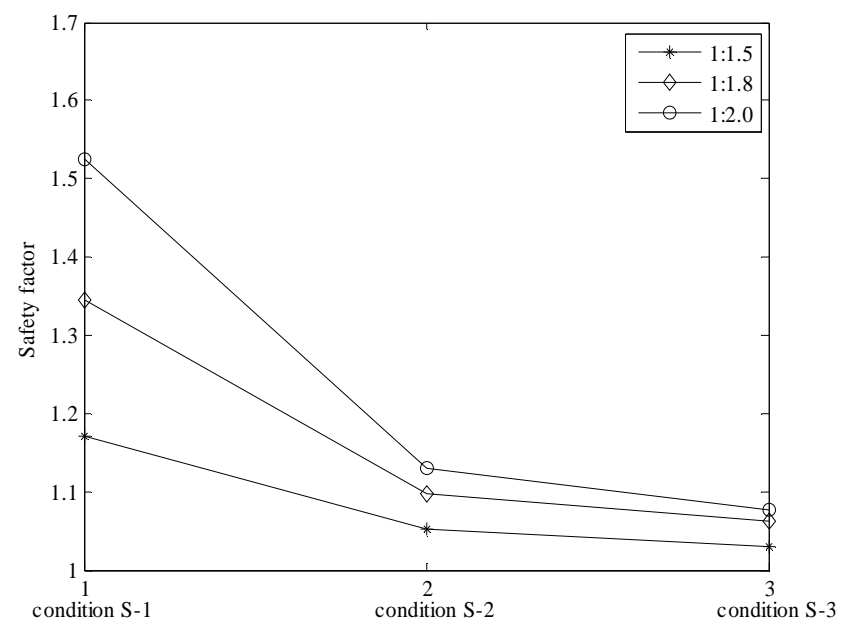

Figure 2. The curve of safety factors and weir slope ratio.

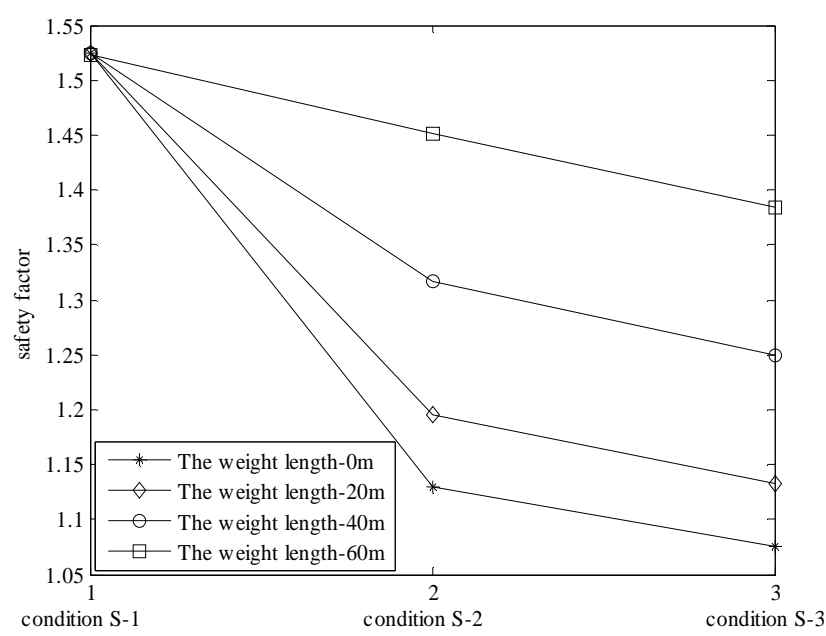

Figure 3 . The curve of safety factors and heavy pressure length 1.

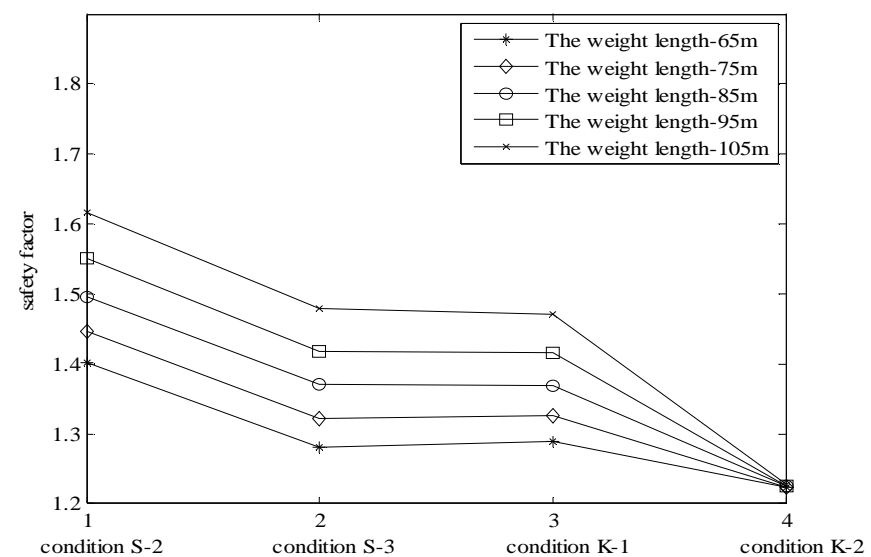

Figure 4 . The curve of safety factors and heavy pressure length 2. 


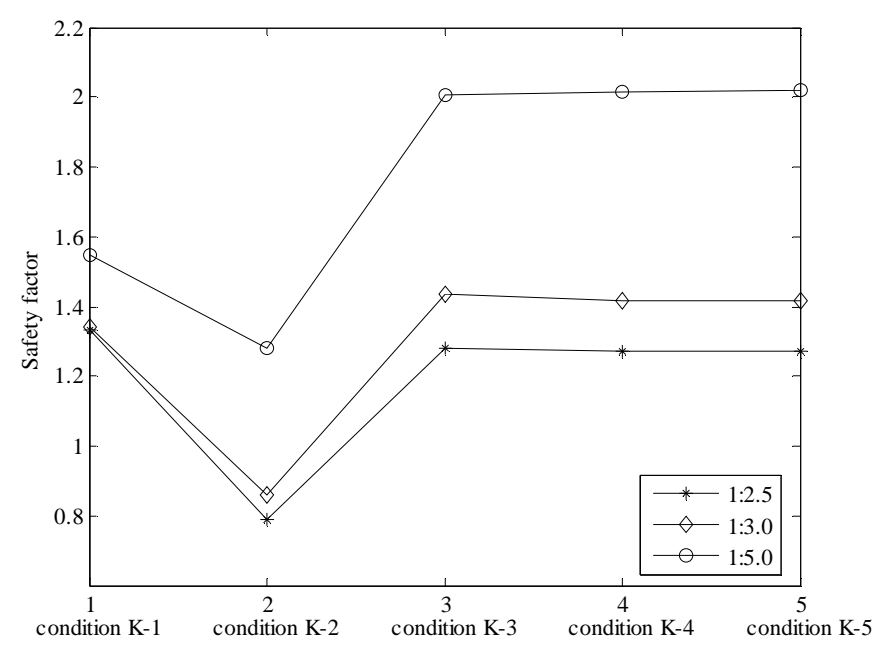

Figure 5. The curve of safety factors and excavation slope ratios.

\section{COMPREHENSIVE TREATMENT SCHEME}

Treatment scheme

According to the study of thick silt foundation reinforcement and measures of increasing slope stabilization to satisfy requirements of this high earth-rock cofferdam and its downstream slope stability of foundation, and combined with practical engineering to put up with comprehensive treatment scheme.

Comprehensive treatment scheme as follows. The high earth rock cofferdam downstream slope ratio is intended to 1:1.6, in elevations of $2589.6 \mathrm{~m}, 2574.6 \mathrm{~m}$ and $2562.6 \mathrm{~m}$ respectively set a 12.5 $\mathrm{m}$ wide berm to achieve the objective of slowing downstream slope. Pit excavation slope ratio is prepared for 1:5 and at the downstream toe add $15 \mathrm{~m}$ high (top elevation is $2553.00 \mathrm{~m}$ ), $75 \mathrm{~m}$ long heavy pressure. Using vibro-replacement stone column as foundation reinforcement measure, and reinforcement length range is from 1:5 foundation pit excavation slope line and (3) layer bottom line intersection to the scope of up stream $60 \mathrm{~m}$, depth range into entire (3) layer and upper $10 \mathrm{~m}$ of (2) layer.

Stability calculation results comparative analysis of comprehensive treatment scheme

Under the comprehensive treatment scheme, the upstream and downstream slope stability calculation results are shown in Table 4. As can be seen, in construction period and the stable seepage period, the most unfavorable conditions of upstream and downstream slope respectively are S-1 that safety factor is 1.331 and S-3 that is 1.322 . During excavation period, the most unfavorable conditions of upstream and downstream slope respectively are K-5 that safety factor is 1.602 and K2 that is 1.306 .

As the comprehensive treatment scheme can satisfy the requirements of all conditions, it is recommended to take comprehensive treatment scheme based on technology feasibly and economic rationally. 
Table 4. The stability calculation results table of comprehensive treatment scheme

* 1 . The minimum safety factor of rules and regulations is 1.30 of $\mathrm{M}-\mathrm{P}$ and simplified Bishop

Safety factors

M-P simplified bishop

Conditions

\begin{tabular}{lccllll} 
& & & Upstream slope & $\begin{array}{l}\text { Downstre- } \\
\text { am slope }\end{array}$ & $\begin{array}{c}\text { Upstre } \\
\text { am slope }\end{array}$ & $\begin{array}{c}\text { Downstre- } \\
\text { am slope }\end{array}$ \\
\hline $\begin{array}{l}\text { construction } \\
\text { period }\end{array}$ & S-1 & E-S & 1.331 & 1.437 & 1.459 & 1.489 \\
$\begin{array}{l}\text { Stable } \\
\text { seepage }\end{array}$ & S-2 & E-S & 1.501 & 1.441 & 1.587 & 1.509 \\
period & S-3 & E-S & 2.675 & 1.445 & 1.371 & 1.448 \\
& $\mathrm{~K}-1$ & E-S & 2.700 & 1.322 & 2.684 & 1.322 \\
& $\mathrm{~K}-2$ & E-S & 3.042 & 1.311 & 2.710 & 1.312 \\
Excavation & $\mathrm{K}-3$ & E-S & 3.212 & 1.306 & 3.057 & 1.304 \\
period & $\mathrm{K}-4$ & E-S & 3.221 & 1.971 & 3.240 & 1.972 \\
& $\mathrm{~K}-5$ & $\mathrm{E}-\mathrm{S}$ & 1.602 & 1.991 & 3.252 & 1.992 \\
& & & & 1.993 & 1.632 & 1.995 \\
\hline
\end{tabular}

method.

2. E-S and T-S represents effective stress and total Stress method respectively.

\section{CONCLUSION}

This article explores reinforcement measures of thick silt foundation and slope stability through the anti-sliding stability analysis of a high earth-rock cofferdam on thick silt foundation, and put forward the comprehensive treatment scheme to solve the problem that stability against sliding of cofferdam and its downstream foundation pit slope. Through this article can draw the following references for other similar projects concluded.

(1)The reinforcement effects of vibro-replacement stone column are remarkable on the thick silt foundation. Piles parameters have greater impact on reinforcement effects of composite foundation. With the decrease of pile spacing, composite foundation shear strength, capacity, standard penetration number of soil between piles and shear wave velocity are increased. As the pile diameter increases, the capacity and settlement are increased. Reasonable pile spacing and pile diameter are key factors to improve shear strength of the thick silt foundation.

(2)The safety factors of cofferdam and foundation pit slope increase along with the corresponding slope ratio's increasing. The heavy pressure has little more significant to safety factors of cofferdam and excavation conditions with little depth.

(3)It is recommended to take comprehensive treatment scheme for solving the problem that slope stability against sliding of high earth-rock cofferdam and its downstream foundation pit on thick silt foundation.

\section{REFERENCES}

[1] Guo,K. \& Wang, Y. 2008. Application of Vibroflotation Sand-gravel Pile on the Deserted FineSand Foundation Soil Treatment in Inner Mongolia. Contemporary Chemical Industry (3): 296-300.

[2] Fu,Y. 2010. Riprap muddy soil reclamation process analysis. Gansu Science and Technology (23): 122-124, 144.

[3] Zheng, Y.R. \& Lu, X. 2000. Research on theory and technology of improving soft clay with DCM. Chinese Journal of Geotechnical Engineering (1) : 18-22. 
[4] Li, M.C. 2008. Mechanism research of the railway foundation reinforcement of the Vibroreplacement stone column in the swamping wetland. SHANXI ARCHITECTURE (21): 286-287.

[5] Wang,Z.K.\&Zhang,X.M.2004.Application of vibro-replacement stone column on the muddy ground. Coal Engineering (6): 29-30.

[6] Zhang,X.G.\&Cao,Y.H. 2007. Application of vibro-replacement crushed stone columns for improvement of soft clay with high liquid limit. China Harbour Engineering (3): 36-37,57.

[7] Technical specification of vibroflotation method foundation treatment in hydropower projects. DL/T5214-2005.

[8] Li,J.Y.2013. Application of foundation treatment with vibro-replacement stone piles to YinPing hydropower station. Chinese Journal of Rock Mechanics and Engineering (z1): 2968-2976.

[9] Yu,Z.\&Zhang,Y.C. 2007. Test study on vibroreplacement stone columns to improvesoft soil foundation. Journal of Chongqing Jianzhu University (6): 57-61.

[10] Lan,B.2005.Analysis and engineering research of vibro-replacement stone column on saturated soft soil foundation. Changsha: Zhongnan university.

[11] Technical specification of ground pile type earth-rockfill dam. DL/T5395-2007. 